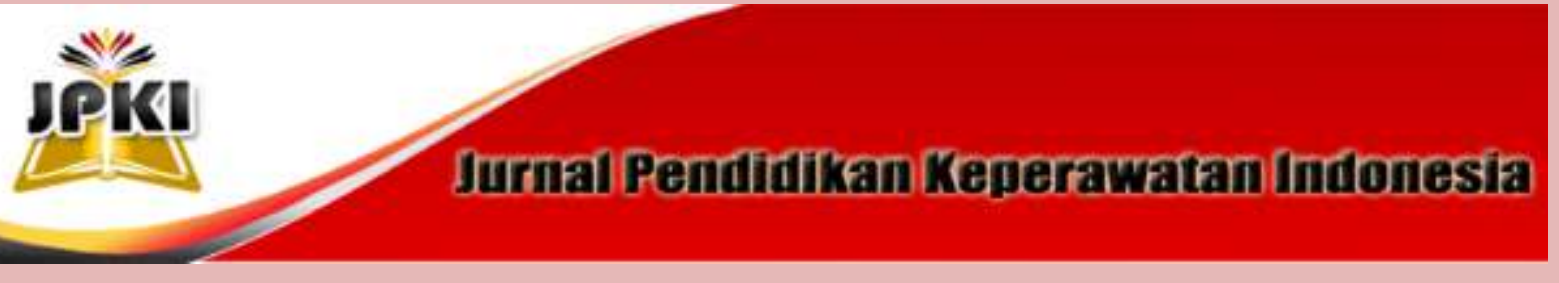

Journal homepage : http://ejournal.upi.edu/index.php/JPKI

\title{
GAMBARAN KEJADIAN POSTPARTUM BLUES PADA IBU NIFAS BERDASARKAN KARAKTERISTIK DI RUMAH SAKIT UMUM TINGKAT IV SARININGSIH KOTA BANDUNG
}

\author{
${ }^{1}$ Lisna Anisa Fitriana, ${ }^{2}$ Siti Nurbaeti \\ ${ }^{1,2,3}$ Prodi D3 Keperawatan FPOK Universitas Pendidikan Indonesia \\ Email : ${ }^{1}$ lisna@upi.edu
}

\begin{abstract}
ABSTRAK
Postpartum blues merupakan fenomena yang terjadi pada hari-hari pertama postpartum. Puncak gejala postpartum blues terjadi pada hari ke-3 sampai ke-5 postpartum dengan durasi mulai dari beberapa jam sampai beberapa hari. Tujuan dari penelitian ini adalah untuk mengidentifikasi Gambaran Kejadian Postpartum Blues Pada Ibu Nifas Berdasarkan Karakteristik di Rumah Sakit Umum TK IV Sariningsih Kota Bandung. Metode dalam penelitian ini adalah deskriptif kuantitatif, dengan teknik pengambilan sampel menggunakan Purposive consecutive Sampling. Jumlah sampel yang diambil sebanyak 40 responden. Intrumen penelitian menggunakan instrument baku yaitu instrument EPDS (Edinburg Postnatal Depression Scale) dengan jumlah soal 10 pertanyaan. Hasil penelitian menunjukkan hampir setengahnya mengalami postpartum blues ringan $(42,5 \%)$ dan hampir setengahnya $(35,0 \%)$ mengalami postpartum blues berat. Berdasarkan usia hampir setengahnya ringan dan berat (30,0\%), berdasarkan pendidikan sebagian kecil ringan (20,0\%), berdasarkan jumlah paritas sebagian kecil ringan $(25,0 \%)$, berdasarkan jenis persalinan hampir setengahnya berat $(27,5 \%)$, berdasarkan jumlah penghasilan perbulan hampir setengahnya ringan $(37,5 \%)$, berdasarkan pekerjaan hampir setengahnya ringan $(30,0 \%)$, berdasarkan status kehamilan sebagian kecil ringan $(22,5 \%)$ dan berdasarkan dukungan sosial hampir setengahnya ringan (35,0\%). Dari hasil penelitian ini dapat disimpulkan bahwa hampir setengahnya ibu nifas di Rumah Sakit Umum TK IV Sariningsih Kota Bandung mengalami postpartum blues ringan dan berat. Adapun rekomendasi dari penelitian ini adalah diadakannya penyuluhan tentang cara mengatasi postpartum blues.
\end{abstract}

Kata Kunci : Kejadian Postpartum Blues, Karakterististik Ibu Nifas

\begin{abstract}
Postpartum blues occurs after giving birth and its symptoms usually happen in the third to fifth days of postpartum and it can last for hours or days. This study has the objective to identify the cases postpartum blues in postpartum mothers seen from their characteristics. This study was conducted at Sariningsih General Hospital (Level IV) Bandung and involved 40 respondents. It particularly uses descriptive quantitative method that applies purposive consecutive sampling. The instrument of this research is EPDS (Edinburg Postnatal Depression Scale) that consists of 10 questions. The findings of this study show that more than half of the respondents experience mild postpartum blues (42.5\%) and almost half them (35\%) experience severe postpartum blues. Following are the findings of this study: seen from the age of the respondents, almost half of them experienced mild and severe postpartum blues (30\%); seen from their education background, few of them experience mild postpartum blues (20\%); seen from the number of parity, few of them experienced mild postpartum blues (25\%); seen from the kinds of labor, some of them experienced severe postpartum blues (27.5\%); seen from their monthly income, almost half of them experienced mild postpartum blues (37.5\%); seen from their occupation, almost half of them experienced mild postpartum blues (30\%);
\end{abstract}


seen from their pregnancy status, few of them experienced mild postpartum blues (22.5\%); and seen from their social support, almost half of them experienced mild postpartum blues (35\%). To conclude, almost half of postpartum mothers at Sariningsih General Hospital (Level IV) Bandung experienced mild and severe postpartum blues. Therefore, it is recommended to educate pregnant women in order to make them well-prepared in avoiding postpartum blues.

Keywords: Postpartum blues cases, postpartum mother characteristics.

\section{PENDAHULUAN}

Melahirkan adalah sebuah karunia terbesar bagi wanita dan momen yang sangat membahagiakan, tapi ada beberapa kasus dapat menjadi momen yang menakutkan hal ini disebabkan pada wanita yang melahirkan sering mengalami perasaan sedih dan takut sehingga mempengaruhi emosional dan sensitifitas ibu yang dikenal dengan istilah postpartum blues (Rahmawati, 2009). Postpartum blues merupakan fenomena yang terjadi pada hari-hari pertama postpartum yang telah dilaporkan sejak akhir abad ke-19. Puncak gejala postpartum blues terjadi pada hari ke-3 sampai ke-5 postpartum dengan durasi mulai dari beberapa jam sampai beberapa hari (Gonidakis, et al., 2007). Adapun Penyebab postpartum blues tidak diketahui secara pasti, tapi diduga dipengaruhi oleh faktor internal dan faktor eksternal.

Suatu penelitian di Negara yang pernah di lakukan seperti di Swedia, Australia, Italia dan Indonesia dengan menggunakan EPDS (Edinburg Postnatal Depression Scale) tahun 1993 menunjukkan 73\% wanita mengalami postpartum blues (Munawaroh, 2008). Prevalensi kejadian postpartum blues dari berbagai negara, berkisar antara 10-34 \% dari seluruh persalinan. Angka kejadian postpartum blues di luar negeri (Jepang) cukup tinggi mencapai 26-85\%. Secara global diperkirakan $20 \%$ wanita melahirkan menderita postpartum blues (Munawaroh, 2008).

Penelitian di Negara barat
menunjukkan kejadian lebih tinggi dibandingkan dengan yang pernah dilaporkan dari asia, pada penelitian yang dilakukan terhadap 154 wanita pasca persalinan di Malaysia pada tahun 2009 dilaporkan angka kejadian 3,9\% terbanyak dari ras India $(8,9 \%)$, Melayu $(3,0 \%)$, dan tidak adanya kasus pada ras Cina. Penelitian di Singapura dilaporkan angka kejadiannya sebesar $1 \%$. Sedangkan penelitian pada tahun 2010 didapatkan angka postpartum blues sekitar 10\%-20\%. Di belanda tahun 2001 diperkirakan 2-10\% ibu melahirkan mengidap gangguan ini (Jofesson A, 2010).
Menurut Bobak (2005) di Indonesia kejadian posrpartum blues yaitu $50-70 \%$ dan hal ini dapat berlanjut menjadi depresi postpartum dengan jumlah bervariasi dari 5\% hingga lebih dari 25\% setelah ibu melahirkan. Dari kantor BKKBN Provinsi Aceh di temukan data bahwa 7 dari 10 ibu yang melahirkan di Provinsi Aceh pada tahun 2012 mengalami depresi berat setelah melahirkan, gejala depresi seperti tidak nafsu makan dan susah tidur merupakan keluhan yang paling sering di utarakan para ibu pasca melahirkan (BKKBN, 2012).

Hasil penelitian yang dilakukan oleh Irawati (2005) di DKI Jakarta menunjukkan 120 dari 580 (25\%) ibu yang menjadi respondennya mengalami sindroma postpartum blues. Dan dari beberapa penelitian yang telah dilakukan di Jakarta, Yogyakarta dan Surabaya, ditemukan bahwa angka kejadiannya 11-30 \%, suatu jumlah yang tidak sedikit dan tidak mungkin dibiarkan begitu saja (Sylvia, 2006).

Berdasarkan penelitian yang dilakukan oleh Setyowati dan Uke (2006), menjelaskan bahwa kemungkinan terjadinya postpartum blues disebabkan oleh pengalaman yang tidak menyenangkan pada periode kehamilan dan persalinan sebanyak 38,71\%. Faktor psikososial (dukungan sosial sebanyak 19,35\%, kualitas dan kondisi bayi baru lahir sebanyak $16,31 \%)$ serta faktor spiritual sebanyak 9,78\% (Machmudah, 2010).

Ibu postpartum blues harus ditangani secara adekuat, karena peran ibu sangat berpengaruh terhadap perkembangan anak juga dalam hubungannya dengan peran ibu di keluarga. Untuk itu seorang ibu yang berada dalam kondisi pasca melahirkan perlu mendapat dukungan dari orang-orang yang ada disekitarnya. Dalam menjalankan peran perawat sebagai pendidik untuk meningkatkan pengetahuan ibu tentang postpartum blues dengan memberikan informasi melalui penyuluhan-penyuluhan agar ibu-ibu pasca melahirkan yang mengalami gangguan psikologis pasca melahirkan tidak jatuh pada gangguan jiwa. 
Berdasarkan studi pendahuluan pada tanggal 11 April 2015 di Rumah Sakit Sariningsih belum pernah diadakan penelitian tentang postpartum blues pada ibu nifas, dan dari studi tersebut didapatkan data yang melahirkan di Rumah Sakit Umum TK IV Sariningsih berjumlah 239 orang dalam waktu 3 bulan terakhir (Januari-Maret 2015). Dari 7 orang ibu nifas di Ruang Nifas Rumah Sakit Umum Sariningsih didapatkan bahwa 2 dari 3 orang ibu nifas dengan persalinan normal mengatakan merasa letih, susah tidur, tampak menangis kesakitan karena luka jahitan, merasa tidak bahagia dan merasa tidak berguna. Sedangkan dari 4 orang ibu nifas dengan persalinan sectio caesarea, terdapat 2 orang diantaranya mengatakan merasa letih dengan operasi tersebut serta merasakan sakit pada luka setelah operasi sehingga takut untuk bergerak, sering merasa sedih jika ASI tidak keluar, merasa cemas, tidak nafsu makan, dan mudah tersinggung.

Berdasarkan latar belakang diatas, peneliti tertarik untuk melakukan penelitian mengenai "Gambaran Kejadian Postpartum Blues Pada Ibu Nifas Berdasarkan Karakteristik di Rumah Sakit Umum TK IV Sariningsih Kota Bandung”.

\section{METODOLOGI}

Metode penelitian ini menggunakan metode deskrptif dengan pendekatan kuantitatif. Populasi dalam penelitian adalah seluruh ibu nifas yang melahirkan di Rumah Sakit Sariningsih sebanyak 239 orang dalam waktu 3 bulan terakhir (Januari-Maret 2015). Sampel dalam penelitian ini sebanyak 40 responden dengan kriteria inklusi dan eksklusi dan pengambilan sampel dalam penelitian ini menggunakan teknik Purposive Consecutive Sampling. Intrument dalam penelitian ini menggunakan intrument baku yaitu instrument EPDS (Edinburgh Postpartum Depression Scale).

\author{
HASIL DAN PEMBAHASAN \\ Kejadian Postpartum blues \\ Tabel 1 Distribusi Frekuensi Kejadian \\ Postpartum Blues dan Karakteristik \\ Responden Penelitian Di Rumah Sakit \\ Umum Tingkat IV Sariningsih
}

\begin{tabular}{|c|c|c|c|c|c|c|}
\hline \multirow{3}{*}{ Variabel } & \multicolumn{6}{|c|}{ Postpartum blues } \\
\hline & \multicolumn{2}{|c|}{ Ringan } & \multicolumn{2}{|c|}{ Sedang } & \multicolumn{2}{|c|}{ Berat } \\
\hline & f & $\%$ & f & $\%$ & $\mathbf{f}$ & $\%$ \\
\hline \multicolumn{7}{|l|}{ Kejadian } \\
\hline \multicolumn{7}{|l|}{ Blues } \\
\hline \multicolumn{7}{|l|}{ Usia } \\
\hline$<20$ tahun & 0 & 0,0 & 0 & 0,0 & 0 & 0,0 \\
\hline 20-35 tahun & 12 & 30,0 & 7 & 17,5 & 12 & 30,0 \\
\hline$>35$ tahun & 5 & 12,5 & 2 & 5,0 & 2 & 5,0 \\
\hline \multicolumn{7}{|l|}{ Pendidikan } \\
\hline SD & 1 & 2,5 & 0 & 0,0 & 2 & 5,0 \\
\hline SMP & 2 & 5,0 & 0 & 0,0 & 3 & 7,5 \\
\hline SMA/SMK & 8 & 20,0 & 7 & 17,5 & 7 & 17,5 \\
\hline Perguruan & 6 & 15,0 & 2 & 5,0 & 2 & 5,0 \\
\hline \multicolumn{7}{|l|}{ Tinggi } \\
\hline \multicolumn{7}{|l|}{ Paritas } \\
\hline Primipara & 7 & 17,5 & 3 & 7,5 & 5 & 12,5 \\
\hline Multipara & 10 & 25,0 & 6 & 15,0 & 9 & 22,5 \\
\hline \multicolumn{7}{|l|}{ Jenis } \\
\hline \multicolumn{7}{|l|}{ Persalinan } \\
\hline $\mathrm{SC}$ & 10 & 25,0 & 5 & 12,5 & 11 & 27,5 \\
\hline Spontan & 7 & 17,5 & 4 & 10,0 & 3 & 7,5 \\
\hline \multicolumn{7}{|l|}{ Penghasilan } \\
\hline \multicolumn{7}{|l|}{ Perbulan } \\
\hline$<1.000 .000$ & 0 & 0,0 & 0 & 0,0 & 0 & 0,0 \\
\hline $\begin{array}{l}1.000 .000- \\
3.000 .000\end{array}$ & 15 & 37,5 & 4 & 10,0 & 10 & 25,0 \\
\hline$>3.000 .000$ & 2 & 5,0 & 5 & 12,5 & 4 & 10,0 \\
\hline \multicolumn{7}{|l|}{ Pekerjaan } \\
\hline Bekerja & 5 & 12,5 & 2 & 5,0 & 3 & 7,5 \\
\hline Tidak & 12 & 30,0 & 7 & 17,5 & 11 & 27,5 \\
\hline \multicolumn{7}{|l|}{ Bekerja } \\
\hline \multicolumn{7}{|l|}{ Status } \\
\hline \multicolumn{7}{|l|}{ Kehamilan } \\
\hline Direncanakan & 8 & 20,0 & 3 & 7,5 & 6 & 15,0 \\
\hline Tidak & & & & & & \\
\hline direncanakan & 9 & 22,5 & 6 & 15,0 & 8 & 20,0 \\
\hline \multicolumn{7}{|l|}{ Dukungan } \\
\hline Sosial & & & & & & \\
\hline Ada & 14 & 35,0 & 7 & 17,5 & 13 & 32,5 \\
\hline Tidak Ada & 3 & 7,5 & 2 & 5,0 & 1 & 2,5 \\
\hline Jumlah & 40 & 100 & 40 & 100 & 40 & 100 \\
\hline
\end{tabular}


Secara psikologis, seorang wanita yang baru saja melahirkan akan mengalami tekanan psikis. Banyak wanita yang sepintas merasa bahagia dengan kelahiran bayinya, namun sejalan dengan itu, akan muncul gangguan suasan hati, perasaan sedih dan tekanan yang dialami oleh seorang wanita setelah melahirkan yang berlangsung pada minggu pertama, terutama pada hari ketiga hingga kelima. Gangguan psikologis tersebut disebut dengan postpartum blues (Hasni, et all., 2012).

Hasil penelitian ini terdapat sebagian besar 40 responden (100\%) ibu nifas di ruang nifas Rumah Sakit Sariningsih mengalami postpartum blues, dikategorikan dengan postpartum blues ringan yaitu 17 responden (42,5\%), postpartum blues sedang yaitu 9 responden $(22,5 \%)$ dan postpartum blues berat yaitu 14 responden $(35,0 \%)$. Jumlah kasus yang ditemukan di ruang nifas Rumah Sakit Sariningsih hampir sama secara internasional maupun nasional. Menurut Bobak (2005) di Indonesia kejadian posrpartum blues yaitu $50-70 \%$ dan hal ini dapat berlanjut menjadi depresi postpartum dengan jumlah bervariasi dari 5\% hingga lebih dari 25\% setelah ibu melahirkan. Angka kejadian postpartum blues di luar negeri (Jepang) cukup tinggi mencapai 26-85\%. Secara global diperkirakan $20 \%$ wanita melahirkan menderita postpartum blues (Munawaroh, 2008).

Penelitian juga ini sejalan dengan penelitian di Ruang Bugenvile RSUD Tugurejo Semarang menunjukkan bahwa 11 orang sebanyak (44\%) menunjukkan terjadi gejala Postpartum Blues (Fatimah, 2009). Hal yang berbeda disampaikan Hasni, et all., (2012) didapatkan data bahwa di puskesmas I Grogol, Sukoharjo yaitu sekitar 10\% dari 92 pasien pasca melahirkan yang mengalami gejala postpartum blues dan hasil kategori pada skala postpartum blues, menunjukkan bahwa 2,5\% wanita pasca melahirkan di Puskesmas Grogol, Sukoharjo mengalami postpartum blues dengan intensitas berat, 22,5\% mengalami postpartum blues dengan intensitas sedang, sedangkan $75 \%$ lainnya mengalami postpartum blues dengan intensitas ringan. Hal ini berarti bahwa secara umum, wanita pasaca melahirkan di Puskesmas Grogol, Sukoharjo mengalami postpartum blues dengan intensitas ringan (Hasni, et all., 2012).

\section{Kejadian Postpartum Blues Berdasarkan Usia}

Hasil penelitian yang didapatkan berdasarkan usia mayoritas responden mengalami postpartum blues ringan hampir setengahnya usia 20-35 tahun yaitu 12 responden $(30,0)$ dan hampir setengahnya $(30,0 \%)$ yaitu 12 responden mengalami postpartum blues berat. Penelitian ini pun sejalan dengan penelitian yang dilakukan Ibrahim, dkk (2012) menunjukkan bahwa responden yang paling banyak mengalami depresi sebagian besar responden dengan kelompok umur 25-29 tahun sebanyak 40,8\%.

Hal yang berbeda penelitian yang dilakukan Irawati (2014) didapatkan bahwa umur yang mengalami postpartum blues adalah usia $<20$ tahun dan $>35$ tahun, usia tersebut merupakan usia berisiko bagi perempuan untuk melahirkan seorang bayi. Kondisi ini tidak sesuai dengan pendapat Bobak (2005), bahwa faktor pencetus terjadinya postpartum blues adalah pada usia remaja atau kurang dari 20 tahun. Hal ini sesuai dengan data BKKBN (2012) yang menyatakan bahwa usia ideal wanita untuk hamil dan melahirkan adalah pada rentang usia 20-35 tahun.

\section{Kejadian Postpartum Blues Berdasarkan Pendidikan}

Hasil penelitian yang didapatkan berdasarkan pendidikan mayoritas responden sebagian kecil berpendidikan SMA/SMK yaitu 8 responden $(20,0 \%)$ mengalami postpartum blues ringan. Hasil penelitian ini sejalan dengan penelitian Murwati (2014) didapatkan bahwa responden yang mengalami depresi postpartum adalah sekolah menengah (SMA-SMK) sejumlah 19 orang $(63,3 \%)$ dan sebagian kecil berpendidikan dasar (SD, SMP) sejumlah 11 orang $(36,7 \%)$.

Penelitian ini juga sejalan dengan penelitian yang dilakukan Soep (2009) didapatkan bahwa hasil proporsi ibu postpartum yang mengalami depresi $51,7 \%$ terjadi pada ibu berpendidikan sedang (pendidikan menengah). Penelitian ini sejalan dengan penelitian yang dilakukan Sabrian (2014) didapatkan bahwa pendidikan yang 
terbanyak adalah perguruan tinggi dengan jumlah 30 orang ibu postpartum $(53,6 \%)$. Hal yang berbeda disampaikan Irawati (2014) bahwa hasil penelitian berdasarkan tingkat pendidikan terbanyak yang mengalami postpartum blues adalah SD - SMP, yaitu 12 responden $(54,5 \%)$.

Hasil penelitian ini menunjukkan bahwa sebagian besar responden memiliki pendidikan yang tinggi. Pendidikan seseorang sangat berpengaruh terhadap pengetahuan dan kesiapan seorang ibu dalam menjalani kehamilan dan persalinan. Hal ini sejalan dengan Latipun (2008) yang mengatakan bahwa pendidikan seseorang akan mempengaruhi cara berpikir dan cara pandang terhadap diri dan lingkungannya karena itu akan berbeda sikap responden yang mempunyai tingkat pendidikan tinggi dibandingkan yang berpendidikan rendah dalam menyikapi proses selama persalinan.

\section{Kejadian Postpartum Blues Berdasarkan Paritas}

Hasil penelitian yang didapatkan berdasarkan paritas mayoritas responden sebagian kecil paritas multipara yaitu 10 responden $(25,0 \%)$ mengalami postpartum blues ringan. Penelitian ini sejalan dengan penelitian yang dilakukan Sabrian (2014) didapatkan bahwa paritas yang terbanyak adalah multipara dengan jumlah 32 orang ibu postpartum $(57,1 \%)$.

Penelitian ini pun sejalan dengan penelitian Murwati (2014) didapatkan hasil penelitian dengan mayoritas multipara sejumlah 20 orang $(66,7 \%)$ dimana jumlah yang mengalami depresi cenderung lebih banyak dari pada primipara bahkan hingga ke tingkat sedang. Hal yang berbeda dengan penelitian Irawati (2014) didapatkan hasil penelitian bahwa sebagian besar responden yang mengalami postpartum blues adalah primipara yaitu 14 responden $(63,6 \%)$. Terdapat hubungan antara paritas dengan kejadian postpartum dengan nilai $\mathrm{p}=0,027$. Hal ini menunjukkan bahwa sebagian besar ibu post partum memiliki pengalaman terhadap kehamilan dan proses persalinan sebelumnya (Miyansaski, 2014).

\section{Kejadian Postpartum Blues Berdasarkan Cara Persalinan}

Hasil penelitian yang didapatkan berdasarkan cara persalinan mayoritas responden hampir setengahnya persalinan SC yaitu 11 responden $(27,5 \%)$ mengalami postpartum blues berat. Penelitian ini sejalan dengan penelitian di RSAL Jala Ammari Makassar tahun 2009 menunjukkan angka kejadian depresi postpartum sebesar $(29,6 \%)$ pada persalinan patologis, sedangkan pada persalinan fisiologis hanya berkisar $(7,0 \%)$ (Pitriani, 2009). Hasil penelitian ini pun sejalan dengan penelitian yang dilakukan Machmudah, dkk (2012) menjelaskan bahwa kemungkinan terjadinya depresi postpartum terjadi pada responden yang mengalami persalinan komplikasi sebesar $53,7 \%$ dan sebesar $46,3 \%$ pada responden yang melahirkan normal.

Hasil penelitian yang disampaikan Ibrahim, dkk (2012) sebagian besar terdapat pada jenis persalinan patologis (caesaria) sebanyak 14 responden $(46,7 \%)$, sedangkan pada persalinan fisiologis (normal) hanya berjumlah 1 responden $(2,2 \%)$. Hal ini sesuai dengan pendapat Kasdu (2007) bahwa ibu yang melahirkan secara operasi akan merasa bingung dan sedih terutama jika operasi tersebut dilakukan karena keadaan darurat. Hal ini pun sesuai dengan pendapat Henshaw (2003) bahwa penyulit persalinan berhubungan dengan terjadinya postpartum blues.

\section{Kejadian Postpartum Blues Berdasarkan Penghasilan Perbulan}

Hasil penelitian yang didapatkan berdasarkan penghasilan perbulan mayoritas responden hampir setengahnya penghasilan 1.000.000-3.000.000 yaitu 15 responden (27,5\%) mengalami postpartum blues ringan. Hasil penelitian sejalan dengan penelitian Irawati (2014) didapatkan hasil penelitian menunjukkan tidak terdapat hubungan yang signifikan antara pendapatan dengan kejadian postpartum blues dengan nilai $\mathrm{p}=0.182$. Hasil penelitian ini tidak sesuai dengan penelitian (Reid V, Oliver, 2007) bahwa pendapatan yang rendah berkontribusi terhadap terjadinya postpartum blues. 
Kondisi ekonomi seringkali membuat psikologi ibu terganggu. Pada keluarga yang mampu mengatasi pengeluaran untuk biaya perawatan ibu selama persalinan, serta tambahan dengan hadirnya bayi baru ini mungkin hampir tidak merasakan beban keuangan sehingga tidak mengganggu proses transisi menjadi orang tua. Akan tetapi keluarga yang menerima kelahiran seorang bayi dengan suatu beban finansial dapat mengalami peningkatan stres, stres ini bisa mengganggu perilaku orang tua sehingga membuat masa transisi untuk memasuki pada peran menjadi orang tua akan menjadi ledih sulit. (Bobak, Laudermilk, Jensen, et all, 2005).

\section{Kejadian Postpartum Blues Berdasarkan Pekerjaan}

Hasil penelitian yang didapatkan berdasarkan pekerjaan mayoritas responden hampir setengahnya dengan ibu yang tidak bekerja yaitu 12 responden $(30,0 \%)$ mengalami postpartum blues ringan. Penelitian ini tidak sejalan dengan penelitian yang dilakukan Sabrian (2014) didapatkan hasil penelitian bahwa yang terbanyak adalah bekerja dengan jumlah 29 orang ibu post partum $(51,8 \%)$. Hal ini pun sesuai dengan Alwi (2005) yang menyatakan bahwa pengetahuan berhubungan dengan pekerjaan dimana secara umum seorang yang bekerja maka pengetahuan akan tinggi karena banyak mendapatkan informasi penting yang dapat menunjang pengetahuannya.

\section{Kejadian Postpartum Blues Berdasarkan Status Kehamilan}

Hasil penelitian yang didapatkan berdasarkan status kehamilan mayoritas responden sebagian kecil kehamilan yang tidak direncanakan yaitu 9 responden $(22,5 \%)$ mengalami postpartum blues ringan. Penelitian ini sejalan dengan penelitian yang dilakukan Irawati (2014) didapatkan hasil penelitian menunjukkan status kehamilan mempengaruhi terjadinya postpartum blues dengan nilai $\mathrm{p}=$ 0,027 . Hasil penelitian ini sesuai dengan Bobak (2005) yang menyatakan salah satu faktor yang dapat menyebabkan postpartum blues adalah kehamilan yang tidak diinginkan.

\section{Kejadian Postpartum Blues Berdasarkan Dukungan Sosial}

Hasil penelitian yang didapatkan berdasarkan dukungan sosial mayoritas responden hampir setengahnya yang mendapat dukungan sosial yaitu 14 responden $(35,0 \%)$ mengalami postpartum blues ringan. Penelitian ini tidak sejalan dengan penelitian yang dilakukan Ibrahim, dkk (2012) menunjukkan bahwa depresi postpartum sebagian besar terdapat pada responden yang kurang mendapat dukungan sosial dari suami yaitu sebanyak 8 responden $(80,0 \%)$ dan hanya 7 responden $(10,6 \%)$ yang mendapat dukungan sosial yang cukup. Sementara yang mendapat dukungan dukungan dari keluarga diri sendiri yaitu sebanyak 8 responden $(53,3 \%)$ yang kurang mendapatkan dukungan sosial dan 7 responden $(11,5 \%)$ pada dukungan sosial cukup.

Menurut Johnson dan Johnson (dalam Oktarina, 2002) salah satu manfaat dukungan sosial adalah pengelolaan terhadap stres dengan menyediakan pelayanan, perawatan, sumber-sumber informasi dan umpan balik yang dibutuhkan untuk menghadapi stres dan tekanan. Sesuai dengan pendapat Nirwana (2011) yaitu faktor yang mempengaruhi postpartum blues adalah faktor psikologis yang meliputi dukungan keluarga khususnya suami. Dalam asuhan pasca persalinan dukungan keluarga sangat diperlukan. Seperti diketahui bahwa di Indonesia, keputusan suami dan arahan dari ibu sangat berpengaruh dan menjadi pedoman penting bagi si ibu dalam praktik asuhan bayinya sehari-hari. Bila suami dan keluarga tidak mendukung, ibu pasca melahirkan biasanya merasa sedih dan kewalahan dalam mengasuh bayinya di harihari pertama setelah melahirkan.

\section{SIMPULAN}

Berdasarkan data penelitian dapat disimpulkan bahwa kejadian postpartum blues pada ibu nifas di Rumah Sakit Umum TK IV Sariningsih Bandung bulan Mei 2015 menunjukkan bahwa hampir setengahnya mengalami postpartum blues ringan dan hampir setengahnya mengalami postpartum blues berat. Dan hampir setengahnya responden berusia 20-35 tahun, sebagian kecil berpendidikan SMA/SMK, sebagian kecil paritas multipara, hampir setengahnya jenis 
persalinan SC, hampir setengahnya mempunyai penghasilan perbulan $1.000 .000-$ 3.000.000, hampir setengahnya ibu yang tidak

\section{DAFTAR PUSTAKA}

Alwi. (2005). Buku ajar fundamental keperawatan. Jakarta: EGC.

BKKBN. (2012). Keluarga berencana. Diperoleh tanggal 25 Maret 2015 dari http://www.bkkbn.go.id/arsip/Default.asp x.

Bobak, Laudermilk, Jensen, et all. (2005). Buku Ajar Keperawatan Maternitas. Jakarta: EGC Creasoft.

Fatimah, Siti. (2009). Hubungan Dukungan

Suami Dengan Kejadian Postpartum Blues Pada Ibu Primipara di Ruang Bugenvile Rsud Tugurejo Semarang.

Artikel Riset Keperawatan. Program Studi Ilmu Keperawatan Fakultas Kedokteran. Universitas

Diponegoro. Diperoleh tanggal 8 Juni 2015 dari http://www.core.ac.uk/download/pdf/117 11002.pdf.

Gonidakis, F., Rabavilas, A.D., Varsou, E., Kreatsas, G., \& Christodoulou, G.N. (2007). Maternity blues in athens, greece: A study during the first 3 days after delivery. Journal of Affective Disorders, 99, 107-115. Diperoleh tanggal $25 \quad$ Maret 2015 dari http://www.jad journal.com.

Hasni, et.all. (2012). Hubungan Antara Citra Tubuh Saat Hamil Dan Kestabilan Emosi Dengan Postpartum Blues Di Puskesmas Grogol Sukoharjo. Program Studi Ilmu Psikologi Fakultas Kedokteran. Universitas Sebelas Maret.

Henshaw, C. (2003). Mood disturbance in the early puerperium: a review. Archives of Women's Mental Health, vol 6, No.2, 33-42. Diperoleh tanggal 25 Maret 2015 dari https://birthpsychology.com/.

Ibrahim, F., Rahma, \& Ikhsan, M. (2012). Faktor faktor yang berhubungan dengan depresi post partum di RSIA Pertiwi Makassar tahun 2012. FKM Unhas. Diperoleh pada tanggal $10 \mathrm{Juni}$ bekerja, sebagian kecil kehamilan yang tidak diingankan dan hampir setengahnya mendapat dukungan sosial.

\section{5 dari \\ http://repository.unhas.ac.id/itstream/ \\ handle/123456789/250/Fatma\%2 \\ Ibrahim\%20(K11108297).pdf?sequence $=$ 1.}

Irawati, D dan Yuliani, F. (2014). Pengaruh Faktor Psikososial Dan Cara Persalinan Terhadap Terjadinya Post Partum Blues Pada Ibu Nifas. Hospital Majapahit (6) 1-7 Vol 6 No. 1 Pebruari 2014. Diperoleh tanggal 15 Maret 2015 dari http://www.poltekkesmajapait.ac.id.

Kasdu, D. (2007). Operasi Caesar, Masalah dan Solusinya. Jakarta: EGC.

Latipun. (2008). Psikologi konseling. Malang: Universitas Muhammadiyah Malang.

Machmudah, T. (2010). Pengaruh Persalinan dengan Komplikasi terhadap kemungkinan terjadinya Postpartum Blues di Kota Semarang. Tesis. Universitas Indonesia. Diperoleh tanggal 31 Maret 2015 dari http://www.lib.ui.ac.id/file?fe=digital/20 284389-T\%20Machmudah.pdf.

Munawaroh, Y. (2008). Faktor Faktor yang Berhubungan dengan Post Partum Blues pada Ibu Pasca Persalinan di Wilayah Kerja PuskesmasKajhu

Kecamatan Baitussalam Kabupaten Aceh Besar. Skripsi. Diploma IV Kebidanan (STIKes) U'Budiyah Banda Aceh. Diperoleh tanggal 21 Maret 2015 dari daa.uui.ac.id/.

Murwati, dan Immaninditya, Y. (2014). Studi Deskriptif Tingkat Depresi Postpartum Pada Ibu Nifas Di Wilayah Kerja Puskesmas Klaten Selatan Tahun 2013. J. Kebidanan Indonesia. Vol. 5, No.1. Januari 2014 (27-34). Diperoleh tanggal 31 Maret 2015 dari https://d3bidanpoltekkessolo files.wordpress.com/.

Reid V, Oliver MM. Postpartum Depression in Adolescent Mothers : An Integrative Review of the Literature. Journal of Pediatric 
Health Care 2007 ; 21 : 289-298. Diperoleh tanggal 9 Juni 2015 dari www.jpedhc.org.

Sabrian, F, Misrawati, Miyansaski, U, A. (2014). Perbandingan Kejadian Post Partum Blues Pada Ibu Post Partum Dengan Persalinan Normal Dan Sectio Caesarea. Program Studi Ilmu Keperawatan Universitas Riau Email: andrew.umaya@yahoo.com

Diperoleh tanggal 10 April 2015 dari https://www.download.portagaruda.org/.

Setyowati., \& Uke.,Riska. (2006). Studi faktor Kejadian Postpartum Blues pada Ibu Pasca Salin : Penelitian deskriptifdi
Ruang Bersalin I RSU

Dr. Soetomo Surabaya. Retrived from

http://www.adln.lib.unair.ac.id/go.php?id =gdlhubgdls1206setyowatiu238\&width= 300\&PHPSESSI $=\mathrm{dd} 2 \mathrm{cc} 1 \mathrm{da} 31030 \mathrm{~d} 55 \mathrm{fcb}$ eb 2daa70d7. Diperoleh tanggal 23 Februari 2010.

Soep. (2009). Pengaruh Intervensi Psikoedukasi Dalam Mengatasi Depresi Postpartum Di RSU Dr.Pirngadi Medan. Tidak dipublikasikan. Diperoleh pada tanggal 11 Juni 2015 dari www.researchgate.net/. 